OPEN ACCESS

Citation: Patcharaporn Chaiyasan, Sumalee Phimphan, Teamjun Sarasan, Sippakorn Juntaree, Alongklod Tanomtong, Sitthisak Pinmongkhonkul, Weerayuth Supiwong (2021) Firstreporton Nucleolar Organizer Regions (NORs) polymorphism and constitutive heterochromatin of Moonlight Gourami, Trichopodus microlepis (Perciformes, Osphronemidae). Caryologia 74(2): 111-119. doi: 10.36253/caryologia-775

Received: April 02, 2020

Accepted: July 27, 2021

Published: October 08, 2021

Copyright: (c) 2021 Patcharaporn Chaiyasan, Sumalee Phimphan, Teamjun Sarasan, Sippakorn Juntaree, Alongklod Tanomtong, Sitthisak Pinmongkhonkul, Weerayuth Supiwong. This is an open access, peer-reviewed article published by Firenze University Press (http://www.fupress.com/caryologia) and distributed under the terms of the Creative Commons Attribution License, which permits unrestricted use, distribution, and reproduction in any medium, provided the original author and source are credited.

Data Availability Statement: All relevant data are within the paper and its Supporting Information files.

Competing Interests: The Author(s) declare(s) no conflict of interest.

\section{First report on Nucleolar Organizer Regions (NORs) polymorphism and constitutive heterochromatin of Moonlight Gourami, Trichopodus microlepis (Perciformes, Osphronemidae)}

\author{
Patcharaporn Chaiyasan ${ }^{1}$, Sumalee Phimphan ${ }^{2}$, Teamjun Sarasan ${ }^{1}$, \\ Sippakorn Juntaree ${ }^{3}$, Alongklod Tanomtong ${ }^{1}$, Sitthisak Pinmongk- \\ HONKUL ${ }^{4}$, WEERAYUTH SUPIWONG ${ }^{3, *}$ \\ ${ }^{1}$ Biology program, Faculty of Science, Khon Kaen University, Muang, Khon Kaen 40002, \\ Thailand \\ ${ }^{2}$ Biology program, Faculty of Science and Technology, Phetchabun Rajabhat University, \\ Phetchabun 67000, Thailand \\ ${ }^{3}$ Faculty of Interdisciplinary Studies, Khon Kaen University, Nong Khai Campus, Muang, \\ Nong Khai 43000, Thailand \\ ${ }^{4}$ Department of Biology, School of Science, University of Phayao, Muang, Phayao 56000, \\ Thailand \\ *Corresponding author. E-mail: supiwong@hotmail.com
}

\begin{abstract}
Nucleolar organizer regions (NORs) polymorphism, constitutive heterochromatin and chromosomal analysis of Moonlight gourami, Trichopodus microlepis in Thailand were firstly reported. Specimens were collected from the Chao Phraya and Mekong Basins, Thailand. The mitotic chromosomes were directly prepared from kidney tissues of ten males and ten females. Conventional staining, Ag-NOR banding and $\mathrm{C}$ - banding techniques were applied to stain the chromosomes. The results shown that the diploid chromosome number of T. microlepis was $2 n=46$ and the fundamental number (NF) was 46 in both males and females. The karyotype consisted of 46 telocentric chromosomes classifying as 14 large and 32 medium chromosomes. No heteromorphic sex chromosome was observed in T. microlepis. The results also showed that the interstitial nucleolar organizer regions (NORs) were clearly observed at the long arm of the chromosome pair 7. This is the first report on NORs polymorphism in T. microlepis that a heteromorphic NOR type in one female had a single NOR-bearing chromosome of the chromosome pair 7 , whereas 10 males and nine females had two NOR-bearing chromosomes of the chromosome pair 7 with a homomorphic NOR type. Constitutive heterochromatin was located at all centromeres of all chromosome pairs. The karyotype formula of T. microlepis is $2 n(46)=\mathrm{L}_{14}^{\mathrm{t}}+\mathrm{M}_{32}^{\mathrm{t}}$.
\end{abstract}

Keywords: Moonlight gourami, Trichopodus microlepis, karyotype, Nucleolar Organizer Region, constitutive heterochromatin, chromosome. 


\section{INTRODUCTION}

Trichopodus which was formerly included in Trichogaster (Peapke, 2009; Töpfer and Schlindler, 2009) is a genus of tropical freshwater labyrinth fish of the gourami or family Osphronemidae and subfamily Trichogastrinae found in Southeast Asia. Gouramis of the Trichopodus genus are closely related to those of Trichogaster (formerly Colisa), species of both genera have long and thread-like pelvic fins (known as "feelers" in the aquarium trade) used to sense the environment. However, Trichopodus species have shorter dorsal fin base and, when sexually mature, are much larger (Peapke, 2009; Töpfer and Schlindler, 2009). There are currently six recognized species in this genus including Trichopodus cantoris, pearl gourami (T. leerii), moonlight gourami (T. microlepis), snakeskin gourami (T. pectoralis), T. poptae and three spot gourami ( $T$. trichopterus) (Peapke, 2009). The moonlight gourami is a labyrinth fish native to the Mekong River in Cambodia, Vietnam and the Chao Phraya Basin, Thailand (Vidthayanon 2005). These fish are silvery coloured with a slightly greenish hue similar to the soft glow of moonlight (Fig. 1). The moonlight gourami's concavely sloped head distinguishes it from other gourami varieties. This peaceful, attractive species is a popular aquarium fish.

Although the gourami fishes are importance for national economy of Thailand, there were quite scarce of cytogenetics in these fishes especially banding analysis in fish chromosomes. The study on fish chromosomes is the basic knowledge which can be applied for the several fields such as classification, evolution, heredity, systematic (Gold et al. 1990, Ueda et al. 2001, Barat et al. 2002, Barat and Sahoo 2007, Supiwong et al. 20019), breeding, rapid production of inbred lines and cytotaxonomy (Kirpichnikov 1981). Furthermore, cytogenetic studies on fish have also been used as biological indicator to determine the ecological toxicology (Klinkhardt 1993, Promsid et al. 2015) and cytogenetic techniques have been widely applied to improve farmed stocks in many aquaculture species in the World (Beardmore et al. 2001, Desprez et al. 2003, Pradeep et al. 2012). An important characteristic of Nucleolar Organizer Regions (NORs) in fish is related to that it has inter- and intra-species polymorphism. NORs characters can be a cytogenetic marker for cytotaxonomic studies and also have been used for studying of phylogenetic relationships among the Cyprinid fishes (Amemyia and Gold 1988, Galetti Jr 1998, AlmeidaToledo et al. 2000). Constitutive heterochromatin distributions on the chromosomes were widely studied in some fish groups (Brinn et al. 2004, Vicari et al. 2006, Mesquita et al. 2008, Takai 2012). Generally, most constitutive heterochromatins locate at centromeric/pericentromeric regions of the chromosomes. Some cases, these heterochromatins can be revealed at interstitial regions in some Pomacentrid fishes to support that the chromosomal evolution in this family is related to the chromosome fusion (Takai 2012). Moreover, constitutive heterochromatin is also highly accumulated on the $\mathrm{W}$ chromosome in Parodon hilarii (Parodontidae) (Moreira-Filho et al. 1993), Characidium fish (Crenuchidae) (Vicari et al. 2008) and Lignobrycon myersi (Triportheidae) (Rodrigues et al. 2016).

As mention before, chromosomal analysis is very important and clearly exhibits the benefits. Moreover, the constitutive heterochromatin and polymorphism of NORs characteristics in the T. microlepis were not studied. Thus, the present study is the first report in $T$. microlepis from Thailand using Ag-NOR banding and C-banding techniques.

\section{MATERIALS AND METHODS}

Sample collection, chromosome preparation and chromosome staining

Ten male and ten female specimens of T. microlepis (Fig. 1) were obtained from the Chao Phraya River, Sing Buri Province, the central part of Thailand and the Mekong Basin, Nong Khai Province, Northeast of Thailand. Chromosomes were directly prepared in vivo as follows by Supiwong et al. $(2013,2017)$. Conventional staining was performed using $20 \%$ Giemsa's solution for 30 min (Rooney 2001). Ag-NOR banding was carried out following by Howell and Black (1980) and C-banding was performed following from the method of Sumner et al. (1972).

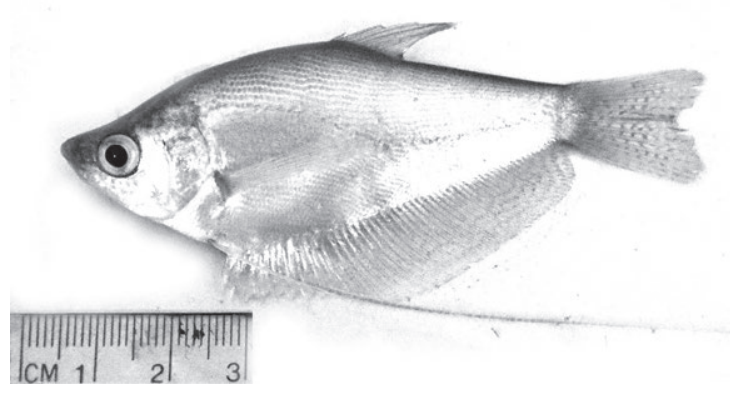

Figure 1. General characteristic of Moonlight Gourami, Trichopodus microlepis (Perciformes, Osphronemidae). 


\section{Chromosomal checks, karyotyping and idiograming}

Chromosome counting was carried out on mitotic metaphase cells under light microscope for 30 cells per specimen to determine the diploid number $(2 n)$. Twenty clearly observable and well-spread metaphase cells from each male and female were selected and photographed. The short arm length (Ls) and the long arm length (Ll) of each chromosome were measured to calculate the total length of the chromosome for 20 well-spread metaphase cells. The chromosome types were classified from method of Turpin and Lejeune (1965) as metacentric, submetacentric, acrocentric and telocentric chromosomes. The karyotyping and idiograming methods were according to Turpin and Lejeune (1965) and Chaiyasut (1989).

\section{RESULTS AND DISCUSSION}

Diploid chromosome number, fundamental number and karyotype

The diploid chromosome number $(2 n)$ of T. microlepis was found as 46 (Figs. 2 and 3). This result is coincident with previous reports by Koref-Santibanez and Paepke (1994) and Seetapan and Khamma-Ai (2007). It is also the same $2 n$ as in the other Trichopodus spp. (Abe

\begin{tabular}{|c|c|c|c|c|c|c|c|}
\hline \multicolumn{8}{|l|}{$\mathbf{A}$} \\
\hline 80 & 0 & 00 & 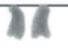 & MV & TV & 01 & 70 \\
\hline 1 & 2 & 3 & 4 & 5 & 6 & 7 & 8 \\
\hline$\sqrt{11}$ & DI & $\mathbf{T}$ & 80 & $7 \pi$ & TIN & 80 & 7 \\
\hline 9 & 10 & 11 & 12 & 13 & 14 & 15 & 16 \\
\hline 01 & 80 & 78 & 81 & 00 & 180 & 8 & \\
\hline 17 & 18 & 19 & 20 & 21 & 22 & 23 & \\
\hline \multicolumn{8}{|l|}{ B } \\
\hline 81 & 81 & DI & 78 & 80 & 81 & 21 & 81 \\
\hline 1 & 2 & 3 & 4 & 5 & 6 & 7 & 8 \\
\hline 70 & 81 & 8 & 81 & 78 & 80 & 85 & A \\
\hline 9 & 10 & 11 & 12 & 13 & 14 & 15 & 16 \\
\hline 10 & 70 & 00 & $2 \pi$ & 18 & $8 \pi$ & $\mathbf{A a}$ & \\
\hline 17 & 18 & 19 & 20 & 21 & 22 & 23 & \\
\hline
\end{tabular}

Figure 2. Karyotypes of male (A) and female (B) of Trichopodus microlepis, $2 n=46$ by conventional staining. Scale bars $=5 \mu \mathrm{m}$.
1975, Koref-Santibanez and Paepke 1994, Donsakul and Magtoon 1988, Seetapan and Khamma-Ai 2007, Magtoon et al. 2007, Supiwong et al. 2010), Trichogaster chuna (Koref-Santibanez and Paepke 1994) and Trichogaster lalius (Abe 1975, Rishi 1976, Koref-Santibanez and Paepke 1994). These species have the diploid chromosome number of $2 n=46$, which is an apparent modal diploid number of the Trichopodus. Accordingly, it can be concluded that chromosome number in this genus is conserved. However, it differs from the most species of the genus Trichogaster (T. labiosa, T. fasciata, T. labiosus, T. sumatranus) which had $2 n=48$ (Kaur and Srivastava 1965, Calton and Denton 1974, Abe 1975, Rishi 1975, Manna and Prasad 1977, Tripathy and Das 1981, KorefSantibanez and Paepke 1994, Rishi et al. 1994, Sobita and Bhagirath 2007, Kushwaha et al. 2008) (Table 1).

The fundamental number (NF) of T. microlepis was 46 in both males and females. The karyotype consisted of 46 telocentric chromosomes (all as mono-arm chromosomes). These results are agreeable with the previous reports of both T. microlepis and all Trichopodus species (Abe 1975, Donsakul and Magtoon 1988, Koref-Santibanez and Paepke 1994, Magtoon et al. 2007, Seetapan and Khamma-Ai 2007, Supiwong et al. 2010). Howev-

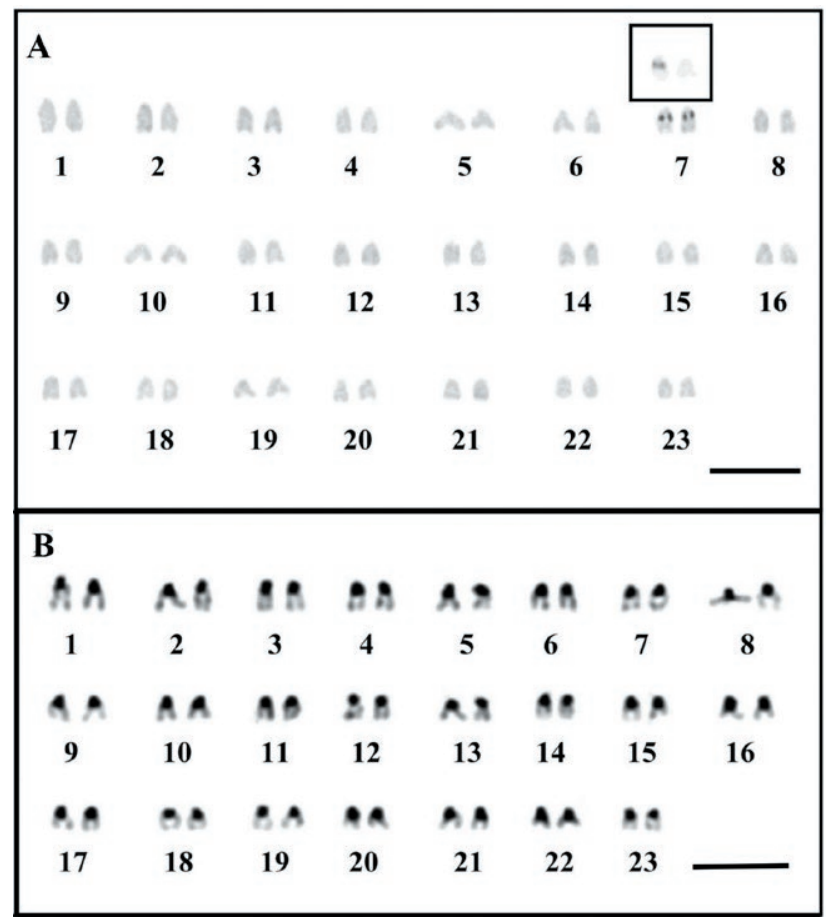

Figure 3. Karyotypes of Trichopodus microlepis, $2 n=46$ by Ag-NOR banding (A) and C-banding techniques (B). The chromosome pair 7 show Ag-NOR and heteromorphic Ag-NOR (inserted box). Scale bars $=5 \mu \mathrm{m}$. 
Table 1. Karyotype characteristics of some species in the subfamily Trichogastrinae.

\begin{tabular}{|c|c|c|c|c|c|}
\hline Species & $2 n$ & NF & Karyotype & NOR & Reference \\
\hline Trichogaster chuna & 46 & 66 & $20 \mathrm{~m}+26 \mathrm{st} / \mathrm{a}$ & - & Koref-Santibanez and Paepke (1994) \\
\hline \multirow[t]{2}{*}{ T. labiosa } & 48 & 66 & $12 \mathrm{~m}+6 \mathrm{sm}+12 \mathrm{st}+18 \mathrm{a} / \mathrm{t}$ & - & Manna and Prasad (1977) \\
\hline & 48 & 68 & $20 \mathrm{~m}+10 \mathrm{st}+18 \mathrm{a} / \mathrm{t}$ & - & Koref-Santibanez and Paepke (1994) \\
\hline \multirow[t]{3}{*}{ T. lalius } & 46 & 70 & $24 \mathrm{~m} / \mathrm{sm}+22 \mathrm{a} / \mathrm{t}$ & - & Abe (1975) \\
\hline & 46 & - & $26 \mathrm{~m}+1 \mathrm{sm} / \mathrm{st}+19 \mathrm{a} / \mathrm{t}$ & - & Rishi (1976) \\
\hline & 46 & 66 & $20 \mathrm{~m}+8 \mathrm{st}+18 \mathrm{a} / \mathrm{t}$ & - & Koref-Santibanez and Paepke (1994) \\
\hline \multirow[t]{8}{*}{ T. fasciata } & 48 & 48 & $48 \mathrm{a} / \mathrm{t}$ & - & Kaur and Srivastava (1965) \\
\hline & 48 & 74 & $14 \mathrm{~m}+12 \mathrm{sm}+22 \mathrm{a} / \mathrm{t}$ & - & Rishi (1975) \\
\hline & 48 & 78 & $8 m+20 s m+12 s t+8 a / t$ & - & Manna and Prasad (1977) \\
\hline & 48 & 78 & $18 \mathrm{~m}+12 \mathrm{sm}+18 \mathrm{a} / \mathrm{t}$ & - & Tripathy and Das (1981) \\
\hline & 48 & 68 & $20 \mathrm{~m}+12 \mathrm{st}+16 \mathrm{a} / \mathrm{t}$ & - & Koref-Santibanez and Paepke (1994) \\
\hline & 48 & $80-81$ & $16 \mathrm{~m}+16 \mathrm{sm}+15 \mathrm{a} / \mathrm{t}(16 \mathrm{a} / \mathrm{t})$ & - & Rishi et al. (1994) \\
\hline & 48 & 83 & $15 \mathrm{~m}+16 \mathrm{sm}+4 \mathrm{st}+13 \mathrm{a} / \mathrm{t}$ & 6 & Sobita and Bhagirath (2007) \\
\hline & 48 & 86 & $16 \mathrm{~m}+16 \mathrm{sm}+6 \mathrm{st}+10 \mathrm{a} / \mathrm{t}$ & 2 & Kushwaha et al. (2008) \\
\hline T. sumatranus & 48 & 48 & $48 \mathrm{st} / \mathrm{a}$ & - & Calton and Denton (1974) \\
\hline \multirow[t]{2}{*}{ Trichopodus leeri } & 46 & 46 & $46 \mathrm{a} / \mathrm{t}$ & - & $\begin{array}{c}\text { Abe (1975) } \\
\text { Koref-Santibanez and Paepke (1994) }\end{array}$ \\
\hline & 46 & 46 & $46 a / t$ & - & Seetapan and Khamma-Ai (2007) \\
\hline \multirow[t]{3}{*}{ T. microlepis } & 46 & 46 & $46 \mathrm{a} / \mathrm{t}$ & - & Koref-Santibanez and Paepke (1994) \\
\hline & 46 & 46 & $46 \mathrm{a} / \mathrm{t}$ & - & Seetapan and Khamma-Ai (2007) \\
\hline & 46 & 46 & $46 \mathrm{t}$ & 2 & Present study \\
\hline \multirow[t]{3}{*}{ T. pectoralis } & 46 & 46 & $46 \mathrm{a} / \mathrm{t}$ & - & Koref-Santibanez and Paepke (1994) \\
\hline & 46 & 46 & $46 \mathrm{a} / \mathrm{t}$ & - & Donsakul. and Magtoon (1988) \\
\hline & 46 & 46 & $46 \mathrm{a} / \mathrm{t}$ & - & Seetapan and Khamma-Ai (2007) \\
\hline \multirow[t]{3}{*}{ T. trichopterus } & 46 & 46 & $46 \mathrm{a} / \mathrm{t}$ & - & Abe (1975), Koref-Santibanez and Paepke (1994) \\
\hline & 46 & 46 & $46 \mathrm{a} / \mathrm{t}$ & - & Magtoon et al. (2007) \\
\hline & 46 & 46 & $46 \mathrm{t} / \mathrm{t}$ & 2 & Supiwong et al. (2010) \\
\hline
\end{tabular}

Remarks: $2 n=$ diploid number, NF = the fundamental number, NOR = Nucleolar Organizer Region, $\mathrm{m}=$ metacentric, $\mathrm{sm}=$ submetacentric, $\mathrm{st}=$ subtelocentric, $\mathrm{a}=$ acrocentric, $\mathrm{t}=$ telocentric chromosomes and $-=$ not available.

er, they are different from all of the genus Trichogaster (Kaur and Srivastava 1965, Calton and Denton 1974, Abe 1975, Rishi 1975, Manna and Prasad 1977, Tripathy and Das 1981, Koref-Santibanez and Paepke 1994, Rishi et al. 1994, Sobita and Bhagirath 2007, Kushwaha et al. 2008). The NFs of the genus Trichogaster range from 48 to 86 and karyotypes composed of both mono- and bi-arm chromosomes. Nirchio et al. (2002) proposed that species with high NF is advanced state or apomorphic character whereas one with low NF is a primitive state or plesiomorphic character. T. microlepis including all species of the genus Trichopodus have all monoarm chromosomes in karyotype whereas most species of the genus Trichogaster display both mono- arm and bi-arm chromosomes (Table 1). Thus, the Trichoprodus seems to be more primitive karyotype than that in the Trichogaster. The T. microlepis karyotype consisted of 14 large telocentric and 32 medium telocentric chromosomes (Table 2). The karyotype formula for this species is $2 n(46)=\mathrm{L}_{14}^{\mathrm{t}}+\mathrm{M}_{32}^{\mathrm{t}}$. There is no evidence of differentiated sex chromosomes in this species which accord to all species of this genus (Abe 1975, Donsakul and Magtoon 1988, Koref-Santibanez and Paepke 1994, Magtoon et al. 2007, Seetapan and Khamma-Ai 2007, Supiwong et al. 2010). Similar to several gourami fishes, no cytologically distinguishable sex chromosome was observed.

\section{Chromosome markers from Ag-NOR banding and C-banding}

Present study was accomplished by using Ag-NOR staining and $\mathrm{C}$-banding in T. microlepis. The NORs are used as makers to detect species specific character and indicate intra- and inter species chromosomal polymorphism in many groups of fishes (Ráb et al. 2008). The Ag-NOR positions were shown on the long arm near the centromere of the telocentric chromosome pair 7 (subcentromeric NOR) in 10 male and nine female fish (Fig. 
Table 2 Mean length of short arm chromosome (Ls), long arm chromosome (Ll), total arm chromosome (LT), relative length (RL), centromeric index (CI) and standard deviation (SD) of RL, CI from 20 metaphases (both males and females) of the Moonlight gourami (Trichopodus microlepis) in Thailand, $2 n=46$

\begin{tabular}{|c|c|c|c|c|c|c|c|}
\hline Chromosome pair & Ls & $\mathrm{Ll}$ & LT & $\mathrm{RL} \pm \mathrm{SD}$ & $\mathrm{CI} \pm \mathrm{SD}$ & Type & Size \\
\hline 1 & 0.000 & 0.755 & 0.755 & $0.0306 \pm 0.0026$ & $1.000 \pm 0.000$ & telocentric & $\mathrm{L}$ \\
\hline 2 & 0.000 & 0.682 & 0.682 & $0.0276 \pm 0.0015$ & $1.000 \pm 0.000$ & telocentric & $\mathrm{L}$ \\
\hline 3 & 0.000 & 0.647 & 0.647 & $0.0261 \pm 0.0011$ & $1.000 \pm 0.000$ & telocentric & $\mathrm{L}$ \\
\hline 4 & 0.000 & 0.621 & 0.621 & $0.0251 \pm 0.0008$ & $1.000 \pm 0.000$ & telocentric & $\mathrm{L}$ \\
\hline 5 & 0.000 & 0.603 & 0.603 & $0.0243 \pm 0.0007$ & $1.000 \pm 0.000$ & telocentric & $\mathrm{L}$ \\
\hline 6 & 0.000 & 0.589 & 0.589 & $0.0237 \pm 0.0006$ & $1.000 \pm 0.000$ & telocentric & $\mathrm{L}$ \\
\hline $7^{\star}$ & 0.000 & 0.578 & 0.578 & $0.0232 \pm 0.0005$ & $1.000 \pm 0.000$ & telocentric & $\mathrm{L}$ \\
\hline 8 & 0.000 & 0.567 & 0.567 & $0.0228 \pm 0.0004$ & $1.000 \pm 0.000$ & telocentric & M \\
\hline 9 & 0.000 & 0.559 & 0.559 & $0.0225 \pm 0.0004$ & $1.000 \pm 0.000$ & telocentric & M \\
\hline 10 & 0.000 & 0.549 & 0.549 & $0.0221 \pm 0.0004$ & $1.000 \pm 0.000$ & telocentric & M \\
\hline 11 & 0.000 & 0.538 & 0.538 & $0.0217 \pm 0.0004$ & $1.000 \pm 0.000$ & telocentric & M \\
\hline 12 & 0.000 & 0.529 & 0.529 & $0.0213 \pm 0.0004$ & $1.000 \pm 0.000$ & telocentric & M \\
\hline 13 & 0.000 & 0.521 & 0.521 & $0.0209 \pm 0.0004$ & $1.000 \pm 0.000$ & telocentric & M \\
\hline 14 & 0.000 & 0.513 & 0.513 & $0.0206 \pm 0.0004$ & $1.000 \pm 0.000$ & telocentric & M \\
\hline 15 & 0.000 & 0.506 & 0.506 & $0.0203 \pm 0.0004$ & $1.000 \pm 0.000$ & telocentric & M \\
\hline 16 & 0.000 & 0.498 & 0.498 & $0.0201 \pm 0.0004$ & $1.000 \pm 0.000$ & telocentric & M \\
\hline 17 & 0.000 & 0.491 & 0.491 & $0.0197 \pm 0.0005$ & $1.000 \pm 0.000$ & telocentric & M \\
\hline 18 & 0.000 & 0.479 & 0.479 & $0.0193 \pm 0.0006$ & $1.000 \pm 0.000$ & telocentric & M \\
\hline 19 & 0.000 & 0.470 & 0.470 & $0.0189 \pm 0.0006$ & $1.000 \pm 0.000$ & telocentric & M \\
\hline 20 & 0.000 & 0.457 & 0.457 & $0.0184 \pm 0.0005$ & $1.000 \pm 0.000$ & telocentric & M \\
\hline 21 & 0.000 & 0.442 & 0.442 & $0.0178 \pm 0.0007$ & $1.000 \pm 0.000$ & telocentric & M \\
\hline 22 & 0.000 & 0.425 & 0.425 & $0.0170 \pm 0.0009$ & $1.000 \pm 0.000$ & telocentric & M \\
\hline 23 & 0.000 & 0.397 & 0.397 & $0.0159 \pm 0.0015$ & $1.000 \pm 0.000$ & telocentric & M \\
\hline
\end{tabular}

Remarks: ${ }^{\star}=$ NOR-bearing chromosome, $\mathrm{L}=$ large, and $\mathrm{M}=$ medium.

3A). The single pair of NOR is the same as in T. trichopterus (Supiwong et al. 2010) and T. fasciata reported by Kushwaha et al. (2008) but there is difference in T. fasciata which had three pairs of NORs (Sobita and Bhagirath 2007) and Betta splendens which had two pairs of NORs (Furgala-Selezniow et al. 2008). Gold and Amemiya (1986) suggested that the occurrence of multiple NORs in fishes was considered to be apomorphic or advance condition whereas single pair of NORs was considered to be plesiomorphic or a primitive condition. Considering for NOR loci between T. microlepis and T. trichopterus, although both species had the single NOR pair, the NOR positions are difference. The present results revealed that $T$. microlepis had interstitial NORs on the chromosome pair 7 whereas T. trichopterus had telomeric NORs (region adjacent to the telomere) on the chromosome pair 2 (Supiwong et al. 2010). Therefore, the NOR-bearing chromosome markers can be used as a tool for classification in this fish group. In addition, intraspecific NOR heteromorphism between the homologous chromosomes of pair 7 was also displayed in one female specimen (Fig. 3A, inserted box). This phenom- enon is common event found previously in several fishes in Thailand such as Puntioplites proctozysron (Supiwong et al. 2012), Lutjanus johnii (Phimphan et al. 2013), Pterapogon kauderni (Kasiroek et al. 2017) and Hemibagrus wyckii (Supiwong et al. 2017).

Constitutive heterochromatic blocks were observed at centromeric and pericentromeric regions of all chromosomes and with no clear interstitial and telomeric positive C-bands (Fig. 3B). It indicates that the chromosomes of T. microlepis are conserved and non-related to chromosomal fusion or an increase in heterochromatin during evolution. Present result is similar to some species in another family of the order Perciformes such as Geophagus brasiliensis and C. facetum in the Cichlidae family (Vicari et al. 2006), Plectroglyphidodon lacrymatus, Chrysiptera leucopoma, C. rex and Neoglyphidodon melas in the Pomacentridae family (Takai 2012). However, there are several species which presented the complex types of positive C-bands. Symphysodon haraldi, S. aequifasciatus and S. discus (Cichlidae) had heterochromatic blocks on the pericentromeric regions of all chromosomes and the proximal regions of both arms of some 


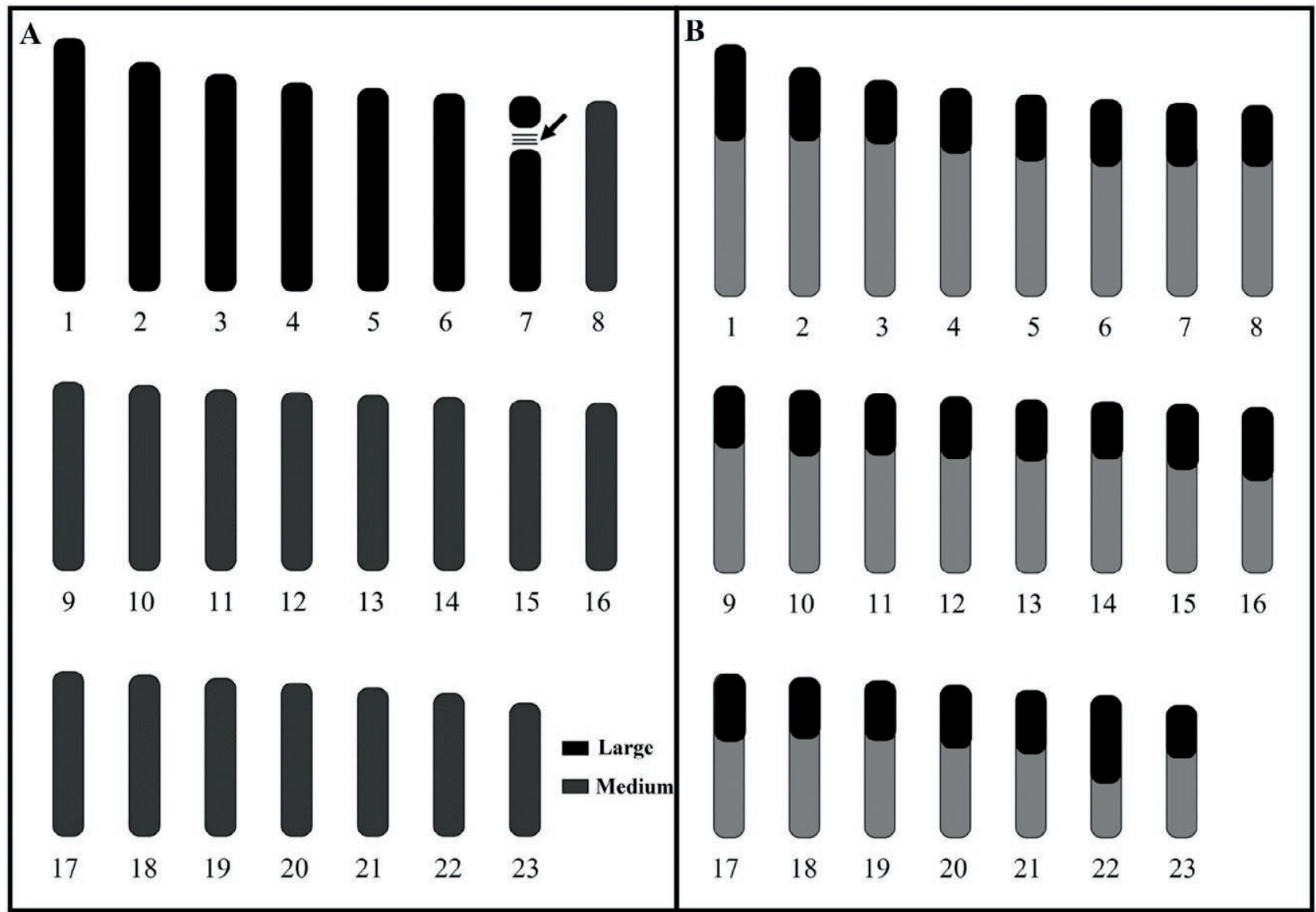

Figure 4. Idiograms showing shape and length of chromosome of Moonlight Gourami, Trichopodus microlepis (Perciformes, Osphronemidae) represented the haploid set $(n=23)$ by conventional staining (A) and C-banding (B). Arrow indicates secondary constriction/NOR on the long arm of the telocentric chromosome pair 7.

chromosomes (Mesquita et al. 2008), while N. nigroris (Pomacentridae) exhibited the distribution of positive C-bands in most centromeric regions and including many terminal and interstitial regions (Takai 2012).

The idiogram shows a continuous length gradation of chromosomes. Approximately two-fold of the size differences between the largest and smallest chromosomes were revealed. The marker chromosomes are the chromosome pair 1 , which is the largest telocentric and the chromosome pair 23 is the smallest telocentric. The data of the chromosome measurement on mitotic metaphase cells (from all specimens) are shown in Table 2. Idiograms by conventional staining and $\mathrm{C}$ - banding are shown in Fig. 4. In conclusion, NOR phenotype and constitutive heterochromatin patterns on the chromosomes are specific to species in the genus Trichopodus. For more information about the chromosomal diversity and chromosomal evolution in this genus, more species and techniques should be further studied.

\section{ACKNOWLEDGMENTS}

Present work was supported by Research and Technology Transfer Affairs (KKU-NKC60-009); the Research Grant of Khon Kaen University through National Research Council of Thailand (Grant no. 6100015); Scholarship under the Post-Doctoral Training Program from Research Affairs and Graduate School, Khon Kaen University (Grant No. 59255); Unit of Excellence for water management research (FF64-UoE006), University of Phayao, and Phetchabun Rajabhat University, Thailand.

\section{REFERENCES}

Abe S. 1975. Karyotypes of 6 species of anabantoid fishes. Chromosomal Information Service 19:5-7.

Amemiya CT and Gold JR. 1988. Chromosomal NORs as taxonomic and systematic characters in North American cyprinid fishes. Genetica 76:81-90. 
Arai R. 2011. Fish Karyotypes: A Check List. Springer, Tokyo.

Barat A and Sahoo PK. 2007. Karyotype analysis of Channa punctatus (Pisces) using restriction endonucleases. Cytologia 72:471-473.

Barat A, Sahoo PK and Ponniah AG. 2002. Karyotype and Nucleolar Organizer Regions (NORs) in a few hill stream fishes. In: Ayyappan, S., Jena, J. K. and Joseph, M. M. (Eds.), The Fifth Indian Fisheries Forum Proceedings, AFSIB, Mangalore and AoA, Bhubaneswar, pp.111-114.

Beardmore JA, Mair GC and Lewis R.I. 2001. Monosex male production in finfish as exemplified by tilapia: applications, problems, and prospects. Aquaculture 197: 283-301.

Brinn MNA, Porto JIR and Feldberg E. 2004.Karyological evidence for interspecific hybridization between Cichla monoculus and C. temensis (Perciformes, Cichlidae) in the Amazon. Hereditas 141:252-257

Calton MS and Denton TE. 1974. Chromosomes of the chocolate gourami: A cytogenetic anomaly. Science 185:618-619.

Chaiyasut K. 1989. Cytogenetics and cytotaxonomy of the family Zephyranthes. Department of Botany, Faculty of Science, Chulalongkorn University, Bangkok, Thailand. (in Thai)

Desprez, D., Mélard, C., Hoareau, M. C., Belleme 'ne, Y., Bosc, P. and Baroiller, J. F. 2003. Inheritance of sex in two ZZ pseudofemale lines of tilapia, Oreochromis aureus. Aquaculture 218:131-140.

Donsakul T and Magtoon W. 1988. A chromosome study on two species of Anabantid fishes, Trichogaster pectoralis and Osphronemus gouramy. In: $14^{\text {th }}$ Congress on Science and Technology of Thailand. E1: pp. 516517.

Furgala-Selezniow G, Fopp-Bayat D, Jankun M, Krejszeff $S$ and Mamcarz A. 2008. Note on the karyotype and NOR location of Siamese fighting fish Betta splendens (Perciformes, Osphronemidae). Caryologia 61:349-353.

Galetti Jr PM. 1998. Chromosome diversity in neotropical fish NOR studies. Ital. J. Zool. 65:53-56.

Galetti PM, Aguilar CT and Molina WF. 2000. An overview of marine fish cytogenetics. Hydrobiologia 420:55-62.

Galetti PM, Foresti F, Bertpllo LAC and Moreira-Filho O. 1984. Characterization of eight species of Anostomidae (Cypriniformes) fish on the basis of the nucleolar organizing region. Caryologia 37:401-406.

Gold JR and Amemiya CT. 1986. Cytogenetic studies in North American minnows (cyprinidae) XII. Pattern of chromosomal nucleolus organizer region variation among 14 species. Can J Zool 65:1869-1877.
Gold JR, Li YC, Shipley NS and Powers PK. 1990. Improved methods for working with fish chromosomes with a review of metaphase chromosome banding. J. Fish Biol. 37:563-575.

Howell WM and Black DA. 1980. Controlled silver-staining of nucleolus organizer regions with a protective colloidal developer: A 1-step method. Experientia 36: 1014-1015.

Kaur D and Srivastava MDC. 1965. The structure and behaviour of chromosome in five freshwater teleosts. Caryologia 18:181-191.

Kirpichnikov VS. 1981. Genetic Bases of Fish Selection. Springer Verlag, Berlin, Heidelberg, New York.

Klinkhardt M. 1993. Fish chromosomes as sensitive toxicity indicators-possibilities and limits. In: Braunbeck, T.H., Hanke W. and Segner, S. (Eds.), Fish in Ecotoxicology and Ecophysiology. Proceedings of an International Symposium, Heidelberg, pp. 45-54.

Koref-Santibanez S and Paepke HJ. 1994. Karyotypes of the Trichogasterinae Liem (Teleostei, Anabantoidei). Abstract of the VIII Congress of the Society of European Ichthyologists. Oviedo, p. 55.

Kushwaha B, Kumar R, Nagpure NS, Behera BK and Lakra WS. 2008. Chromosome banding in two freshwater gouramies from northeastern India. Nucleus 51: $61-72$.

Manna GK and Prasad R. 1977. Chromosome analysis of five species of fresh water fishes. Nucleus 20:264-271.

Mani I, Kumar R, Singh M, Kushwaha B, Nagpure NS, Srivastava PK, Murmu K, Rao DSK and Lakra WS. 2009. Karyotypic diversity and evolution of seven mahseer species (Cyprinidae) from India. Journal of Fish Biology 75:1079-1091.

Mesquita DR, Porto JIR and Feldberg E. 2008. Chromosomal variability in the wild ornamental species of Symphysodon (Perciformes: Cichlidae) from Amazon. Neotrop. Ichthyol. 6:181-190.

Nirchio M, Turner BJ, Perez JE, Gaviria JI and Cequea H. 2002. Karyotypes of three species of toadfish (Batrachoididae: Teleostei) from Venezuela. Sci. Mar. 66:1-4.

Peapke, H-J. 2009. The nomenclature of Trichopodus pectoralis Regan, 1910; Trichopodus cantoris Sauvage, 1884 and Osphronemus saigonensis Borodin, 1930 (Teleostei: Perciformes: Osphronemidae). Vertebrate Zoology. Dresden: Museum für Tierkunde Dresden 59:53-60.

Phimphan S, Tanomtong A, Jumrusthanasan S, Supiwong W, Siripiyasing $\mathrm{P}$ and Sanoamuang L. 2013. First report of NOR polymorphism and chromosome analysis of John's snapper, Lutjanus johnii (Perciformes, Lutjanidae) in Thailand. Cytologia 78:335-344. 
Pradeep PJ, Srijayaa TC, Papini A and Chatterji AK. 2012. Effects of triploidy induction on growth and masculinization of red tilapia [Oreochromis mossambicus (Peters, 1852) X Oreochromis niloticus (Linnaeus, 1758)]. Aquaculture 344-349: 181-187.

Promsid P, Neeratanaphan L, Supiwong W, Sriuttha M and Tanomtong A. 2015. Chromosomal aberration of Snakehead fish (Channa striata) in affected reservoir by leachate with lead and mercury contamination. International Journal of Environmental Research. 9(3): 897-906.

Ráb P, Rábova' M, Pereira C, Collares-Pereira MJ and Pelika'nova S. 2008. Chromosome studies of European cyprinid fishes: Interspecific homology of leuciscine cytotaxonomic marker-the largest subtelocentric chromosome pair as revealed by crossspecies painting. Chromosome Res. 16:863-873.

Rishi KK. 1975. Somatic and meiotic chromosomes of Trichogaster fasciatus (Bl. et Sch.) (Teleostei, Perciformes, Osphronemidae). Genen en phaenen 18:49-53.

Rishi KK. 1976. Karyotypic studies on four species of fishes. Nucleus 19:95-98.

Rishi S, Rishi KK and Gill PPK. 1994. Chromosomal banding studies in Colisa fasciatus (Osteyichthyes) and analysis of female heterogamety. Abstract VIII Congress of the Society of European Ichthyologists Oviedo, p.59.

Rodrigues AS, Medrado AS, Diniz C, Oliveira PR, Affonso AM. 2016. ZZ/ZW sex chromosome system in the endangered fish Lignobrycon myersi MirandaRibeiro, 1956 (Teleostei, Characiformes, Triportheidae). Comp. Cytogenet. 10:245-254

Rooney DE. 2001. Human Cytogenetics: Constitutional Analysis, A Practical Approach. Oxford, Oxford University Press.

Seetapan K. 2007. Karyotypes of sex fish species of the family Cyprinidae. In: Proceedings of the 45th Kasetsart University Annual Conference. Kasetsart University, Bangkok, pp. 749-758. (in Thai)

Seetapan K and Khamma-Ai M. 2007. Karyotypes of the genus Trichogaster from Thailand. In: The Proceedings of Fisheries Annual Conference. Bangkok, Thailand, pp. 323-329.

Sobita N and Bhagirath T. 2007. Colisa fasciata (Schneider) (Perciformes, Anabantoidei, Belontidae): karyotype is divergent and ZW sex chromosomes are allocyclic and asynaptic. Nucleus 50:45-49.

Sumner AT. 1972. A simple technique for demonstrating centromeric heterochromatin. Exp. Cell Res. 74:304306.

Supiwong W, Boonsuk J, Jantarat S, Suvarnaraksha A, Pengseng $\mathrm{P}$ and Tanomtong A. 2017. The first chro- mosomal characteristics of nucleolar organizer regions and karyological analysis of two chaetodontid fishes (Perciformes, Chaetodontidae). Cytologia $82: 33-39$.

Supiwong W, Pinthong K, Seetapan K, Saenjundaeng P, Bertollo LAC, de Oliveira E A, Yano CF, Liehr T, Phimphan S, Tanomtong A. and Cioffi MB. 2019. Karyotype diversity and evolutionary trends in the Asian swamp eel Monopterus albus (Synbranchiformes, Synbranchidae): a case of chromosomal speciation? BMC Evolutionary Biology 19:73. https://doi. org/10.1186/s12862-019-1393-4

Supiwong W, Tanomtong A, Chaveerach A, Tanee T, Khakhong $S$ and Sanoamuang L. 2013. Interpopulational variation of NOR positions and karyotypic analysis of Siamese catfish (Pseudomystus siamensis) in Thailand. Cytologia 78:25-34.

Supiwong W, Tanomtong A, Kenthao A, Seetapan K and Kaewsri S. 2010. Standardized karyotype and ideogram of the three-spot gourami, Trichogaster trichopterus (Perciformes, Belontidae) from Thailand by conventional staining and Ag-NOR staining techniques. The Nucleus 53:103-107.

Supiwong W, Tanomtong A, Supanuam P, Jantarat S, Khakhong S. and Sanoamuang S. 2012. A discovery of nucleolar organizer regions (NORs) polymorphism and karyological analysis of Smith's barb, Puntioplites proctozysron (Cypriniformes, Cyprinidae) in Thailand. Cytologia 77:35-42.

Takai A. 2012. Chromosomal distribution of C-band-positive heterochromatin in eight species of Pomacentridae (Perciformes). Chromosome Science 15:39-42.

Töpfer J and Schlindler I. 2009. On the type species of Trichopodus (Teleostei: Perciformes: Osphronemidae). Vertebrate Zoology. Dresden: Museum für Tierkunde Dresden. 59:49-51.

Tripathy NK and Das CC. 1981. The karyotype of Trichogaster fasciatus (Osphronemidae, Pisces). Curr. Sci. 50:916-917.

Turpin R. and Lejeune J. 1965. Les Chromosomes Humains. Gauthier-Pillars, Paris.

Ueda T, Iijima K, Naoi H, Arai R, Ishinabe T and Jeon SR. 2006. Karyotypes of three Tanakia Bitterlings (Pisces, Cyprinidae) from East Asia. Cytologia 71:251-255.

Ueda T, Naoi H and Arai R. 2001. Flexibility on the karyotype evolution in bitterlings (Pisces, Cyprinidae). Genetica 111:423-432.

Vicari MR, Artoni RF, Moreira-Filho $\mathrm{O}$ and Bertollo LAC. 2006. Basic and molecular cytogenetics in freshwater Cichlidae (Osteichthyes, Perciformes). Karyotypic conservationism and divergence. Caryologia. 59:260-266. 
Vicari MR, Artoni RF, Moreira-Filho $\mathrm{O}$ and Bertollo LAC. 2008. Diversification of a ZZ/ZW sex chromosome system in Characidium fish (Crenuchidae, Characiformes). Genetica 134:311-317.

Vidthayanon C. 2005. Handbook of Freshwater Fish. 2nd ed. Sarakadee Press, Bangkok. (in Thai) 